\title{
The rigid spine syndrome
}

\author{
E T L VAN MUNSTER, E M G JOOSTEN, M A M VAN MUNSTER-UIJTDEHAAGE, \\ H J A KRULS, H J TER LAAK
} From the Institute of Neurology and Institute of Orthopaedics, St Radboud Hospital, University of Nijmegen,
The Netherlands

SUMMARY Four patients are reported, 3 females and 1 male, with (as a prominent symptom of muscle disease) limitation of flexion of cervical and dorsolumbar spine. The nosological classification of these cases is discussed. In two patients there was evidence of an inclusion body myositis. At necropsy one of these patients had a remarkable distribution of muscle changes.

The rigid spine syndrome is an unusual muscular disorder first described in 1965 by Dubowitz, ${ }^{1}$ and later on by the same author ${ }^{2-4}$ and several others. $^{5-17}$ The syndrome is clinically characterised by limitation of flexion of the cervical and dorsolumbar spine, caused by a shortening of the erector trunci muscles, without severe pareses. Initially, extension of the spine is not or only slightly restricted. Furthermore, there is proximal muscle weakness, usually only slight and nonprogressive. Scoliosis can be progressive; there are often flexion contractures affecting elbows, knees and feet, waddling gait and difficulty in going upstairs. Several authors ${ }^{6-11}$ mentioned that many patients have hardly any subcutaneous fat. Twenty-three patients mentioned in the literature showed an almost identical clinical pattern. ${ }^{1-16}$ Nearly all cases occur sporadically. The time of onset is in childhood. Creatine kinase (CK) levels are variably elevated. Electromyography (EMG) of the erector trunci muscles shows a myopathic pattern. Biopsy findings from quadriceps or erector trunci muscles show a nonspecific myopathy; there is often a type I fibre predominance.

\section{Case reports}

Case 1 This 19-year-old woman was the child of healthy nonconsanguineous parents, born after a normal pregnancy and uncomplicated delivery. Her development proceeded normally until the age of 7 years, when her running speed

Address for reprint requests: Dr Joosten, Institute of Neurology, St Radboud University Hospital, Box 9101, 6500 HB Nijmegen, The Netherlands.

Received 26 July 1985 and in revised form 24 December 1985. Accepted 13 January 1986 decreased and she tended to walk on her toes. By age 12 years, there was an apparent rigidity of the spine, and she had difficulty going upstairs. Her body weight decreased. Limitation of neck- and back-flexion progressed slowly over the next years. Lumbar lordosis was exaggerated to $112^{\circ}$ at the age of 19 years. Gradually, respiratory capacity became impaired, partly because of extreme flattening of her chest; the midsagittal diameter from spine to sternum and from spine to abdominal wall was only $4.5 \mathrm{~cm}$ (fig 1). Muscle weakness in arms and legs was not apparently progressive. Her intelligence was normal and there was no family history.

Examination revealed a very thin girl with acrocyanosis, a deformed very flat chest, winged shoulders and rigid spine with striking flxed lordosis (fig 2). Anteflexion of the cervical and lumbar spine was nearly impossible, while extension, rotation and lateral flexion were also already limited. There were flexion contractures of hips, knees and feet. The extremity weakness was moderate, more proximal than distal, while pelvic girdle muscles were more affected than shoulder girdle muscles. There was no gross atrophy. Respiratory movements of the chest were not strong and with little excursion. Tendon reflexes were symmetrically sluggish. There were no sensory abnormalities.

Radiological examination of the spine revealed a slight thoracic left convex scoliosis of $10^{\circ}$. Lateral radiographs showed a striking cervical and lumbar hyperlordosis. No ankylosis or destructive lesions were noted, or osseous pathology, ECG was initially normal, later on right axis deviation was seen.

Laboratory findings: CK levels were increased (about 3 to 5 times normal levels) at several occasions. Routine blood and urine examination was normal. There was no evidence of specific infections. Alpha-glucosidase activity in leucocytes was normal. Karyotyping of leucocytes showed no abnormalities (no XO anomaly). Respiratory function tests revealed a restrictive defect (vital capacity 1.350 1; normal 4.400 1). EMG of the erector spinae muscle showed a myopathic pattern. Motor and sensory conduction were normal.

Muscle biopsy findings (see table 1): The first biopsy was on the quadriceps muscle at age 16. At age 19, a biopsy specimen was taken from the erector trunci muscle. Light microscopy of both specimens was similar, but the second 


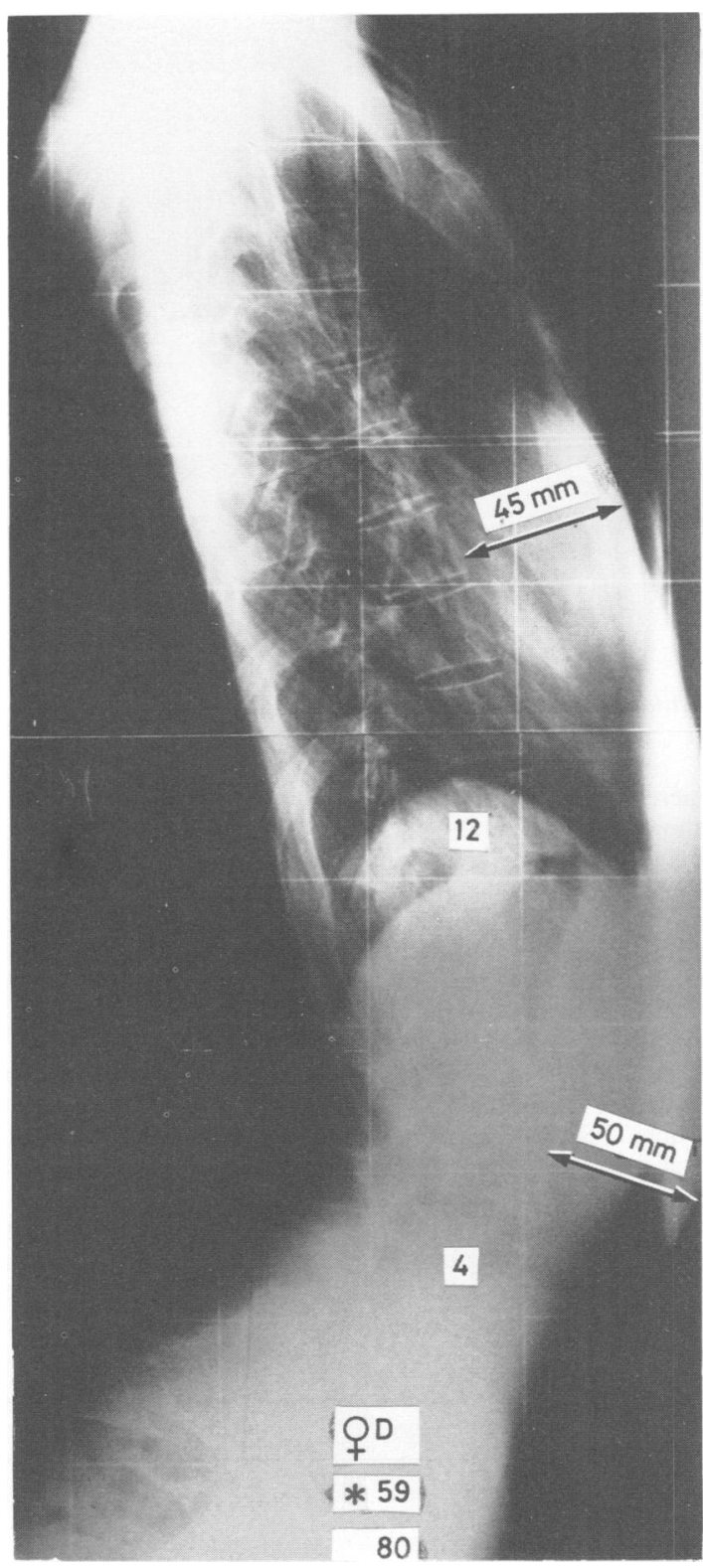

Fig 1 Lateral radiograph of patient 1 shows a highly flattened chest and increased lumbar lordosis.

showed much more severe abnormalities. Endomysial connective tissue proliferation was striking (fig 3). There were many vacuoles, often filled with basophilic and granular material. There was increased variation in fibre diameter. Fibre splitting could often be seen. Sometimes, a small focus of inflammation was seen. There was some evidence of grouped atrophy. In the first biopsy specimen, there was no type I or type II fibre predominance; the second showed a predominance of type I fibres. Electron microscopy showed myxovirus-like particles, as seen in cases of inclusion body myositis. ${ }^{18}$ Biochemical investigation revealed no alphaglucosidase deficiency.

Death occurred at the age of 20 years from an acute cor pulmonale. At necropsy the following muscles were examined: erector trunci, psoas, pectoral, intercostal and diaphragm. In most there was evidence of necrotising myopathy with vacuolation, especially severe in the diaphragm muscles (fig 4).

The features in this case are quite similar to those of the rigid spine syndrome as described by Dubowitz; ${ }^{4}$ a slowly nonprogressive disease affecting most strikingly the extensors of the spine, with contractures of hip, knee and ankle muscles.

Case 2 At the age of 3 years, this girl was referred to the neurological department. She is the second child of healthy, nonconsanguineous parents. She has four healthy sibs. There is no family history of neurological or orthopaedic diseases. Pregnancy and delivery were uncomplicated. The motor development proceeded normally until the age of 4 years, when it was noticed that she had a disability in running. Later on, difficulty in going upstairs became apparent. Also there was a restricted forward flexion of the neck, which became slowly progressive until now. Mental function is normal and there is no cardiac or pulmonary abnormality. Her handicap is mild.

Examination revealed a thin girl with a restricted anteflexion of the neck and a fixed lumbar lordosis, while extension of the spine is unlimited and of normal strength. Scoliosis is mild. There are slight contractures of elbows and she is walking on her toes. She has pes cavus. Musculature is thin with mild proximal pareses of all extremities. Trendelenburg and Gowers signs are positive. Tendon reflexes are absent. This patient has hardly any subcutaneous fat.

Radiological examination showed no osseous pathology. ECG and echocardiography revealed no cardiomyopathy. Mitral valve prolapse is present without clinical significance.

Laboratory findings: increased serum CK level (about 4 times normal level). There are no other abnormalities. EMG shows no specific pathology. There are normal motor and sensory conduction velocities.

Muscle biopsy findings (see table 1): A biopsy specimen was taken from the erector trunci muscle. Light microscopy: connective tissue was increased and there are several myopathic features. There was no fibre type predominance. Electron microscopy: infrequent inclusion bodies were present.

The clinical picture is in agreement with rigid spine syndrome. Only progression of muscle weakness in the future would cast doubt upon the diagnosis.

Case 3 From the age of 7 years this girl was treated with a Milwaukee brace because of a progressive thoracic scoliosis. At age 15, she was referred to the neurological department when she was suspected of the rigid spine syndrome. She is the second child of healthy nonconsanguineous parents. Pregnancy was uncomplicated; however, the delivery was difficult because of contractures of hands and feet. She was "floppy". Her motor development was retarded. After the age of 10 , the illness showed little progress and after her 16th year it became stabilised. There is no family history of a similar disease. 


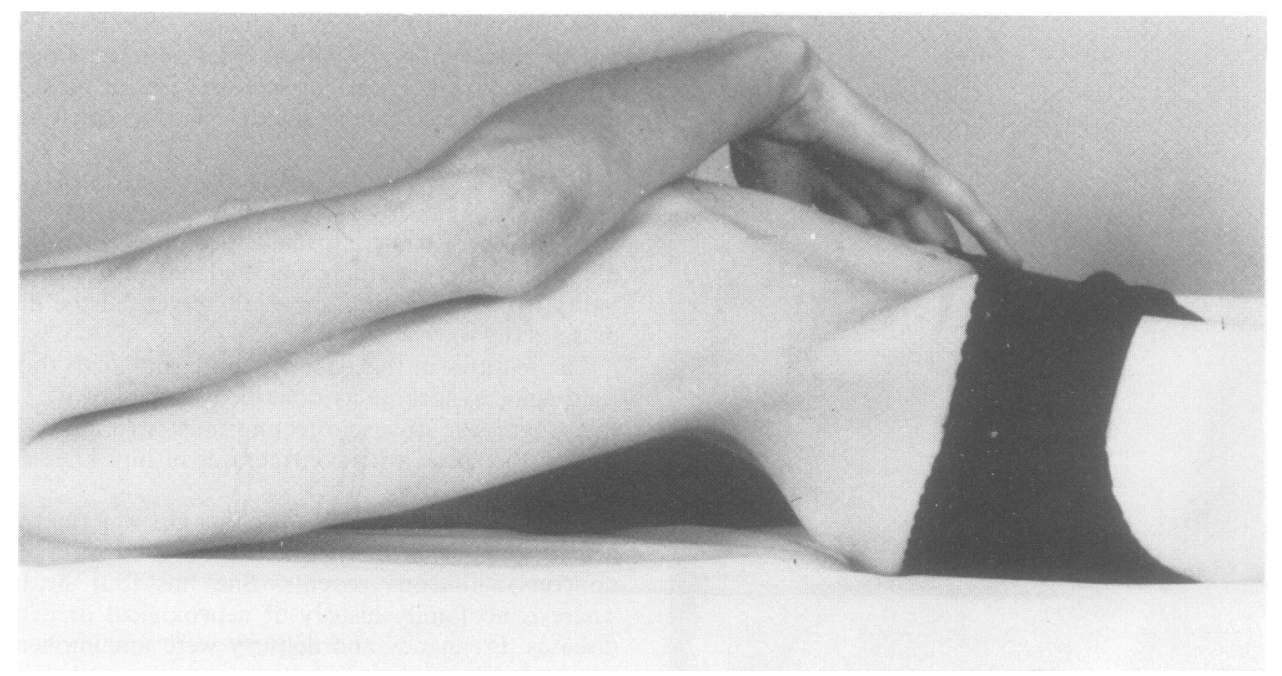

Fig 2 The striking fixed lordosis in patient 1 in supine position.

On examination there was noted a thin girl with almost no subcutaneous fat. Congenital contractures of hands and feet had been surgically corrected. A thoracic scoliosis with flattening of the chest was present; her midsagittal body diameter was less than $10 \mathrm{~cm}$. Flexion of the neck and lumbar spine was extremely limited, but extension and torsion were of normal strength. The musculature was hypoplastic and hypotonic with slight pareses, especially in the sternocleidomastoideus muscle and erector trunci muscles.

Radiographs showed no osseous pathology. ECG was normal. Laboratory findings only revealed slightly elevated CK levels (1.5 times normal levels). Respiratory function tests showed a restricted function. EMG showed generalised myopathy, most severe in the erector trunci muscle, with normal conduction velocities.

Muscle biopsy findings (table 1): Light microscopy: in $\mathbf{m}$. erector trunci biopsy some vacuoles were seen; there was an increase of connective tissue; a large number of fibres showed central nuclei; there was a large variation in fibre diameter. Type I fibre predominance was evident. Because of the absence of subcutaneous fat by clinical examination a skin biopsy was performed: subcutaneous fat lobes and the number of fat cells were diminished, without specific abnormalities. Sweat glands and capillaries were normal. Electron microscopy provided no additional information. In the muscle tissue the alpha-glucosidase level was normal.

In this case it seems that the rigid spine is probably a symptom of the basic illness, a congenital muscular dystrophy. Severe problems already existed at delivery, especially the contractures of hands and feet, which disappeared completely. The rigid spine developed later on.

Case 4 This 37-year-old man was the eldest offspring of healthy nonconsanguineous parents. Pregnancy and birth were unremarkable. His family history showed no specific

Table 1 Muscle biopsy findings

\begin{tabular}{|c|c|c|c|c|}
\hline & Case I & Case 2 & Case 3 & Case 4 \\
\hline $\begin{array}{l}\text { Percentage type I fibres } \\
\text { Diameter range }(\mu \mathrm{m}) \text { : type I fibres } \\
\text { type II fibres } \\
\text { Fibres with internal nuclei } \\
\text { Percentage fibre splitting } \\
\text { Fibre fragmentation } \\
\text { Basophilic fibres } \\
\text { Vacuoles in fibres } \\
\text { Phagocytosis } \\
\text { Cell infiltration } \\
\text { Angular atrophic fibres } \\
\text { Fibres with nuclear clumps } \\
\text { Type grouping } \\
\text { Terminal innervation ratio (TIR) } \\
\text { Fatty cells } \\
\text { Connective tissue }\end{array}$ & $\begin{array}{l}65 \% \\
10-185 \\
10-154 \\
47 \% \\
2 \% \\
+ \\
++ \\
+++ \\
+ \\
+ \\
+ \\
+ \\
++ \\
1 \cdot 79 \\
+ \\
+++\end{array}$ & $\begin{array}{l}51 \% \\
23-88 \\
23-88 \\
44 \% \\
1 \% \\
- \\
+ \\
- \\
+ \\
- \\
- \\
+ \\
1 \cdot 33 \\
+++ \\
+++\end{array}$ & $\begin{array}{l}94 \% \\
30-126 \\
88-172 \\
63 \% \\
3 \% \\
+ \\
+ \\
- \\
- \\
- \\
+ \\
1 \cdot 22 \\
++ \\
+++\end{array}$ & $\begin{array}{l}0 \% \\
5-20 \\
5-20 \\
0 \% \\
0 \% \\
- \\
- \\
- \\
- \\
- \\
- \\
+ \\
\text { nd } \\
\text { nd } \\
15 \% * \\
84 \% *\end{array}$ \\
\hline
\end{tabular}

nd = not determined; ${ }^{*}=$ of surface area; $-=$ absent $+=$ present $++=$ increased; $+++=$ severely increased. 


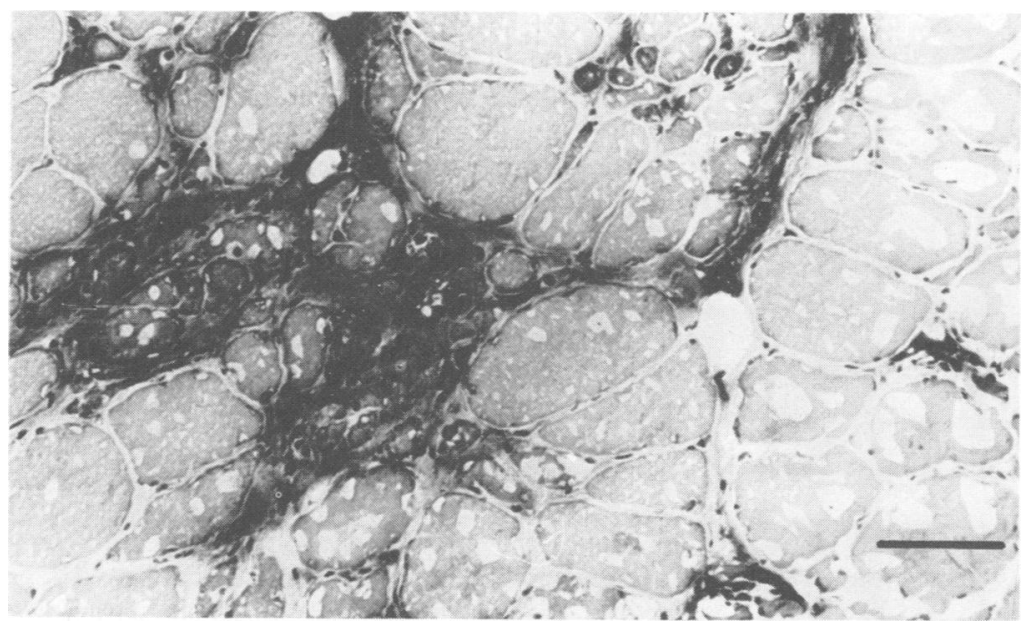

Fig 3 Erector trunci muscle. Dark staining connective tissue is present between the muscle fibres (5'-nucleotidase, bar $100 \mu \mathrm{m})$.

illness, especially no muscle diseases. In his early infancy he was suspected of having Duchenne muscular dystrophy; however, the clinical course was too mild for this diagnosis to be sustained. The onset of his illness was in his 3rd year, when he began walking on his toes because of contractures of his ankles. At the same time other contractures developed. There were progressive pareses, especially of his shoulder and hip girdles. He had a waddling gait. Later on lumbar hyperlordosis and cervical stiffness arose. Several times he underwent orthopaedic surgical treatments. His illness was progressive; in his 25 th year he became unable to walk. Until now, severe pareses and contractures have progressed slowly. There are no pulmonary or intellectual defects, and no cardial complaints.

Physical examination revealed a very disabled man with little subcutaneous fat. There were severe flexion contractures of nearly all his great joints. Extensive pareses were present, espcially of axial-, shoulder- and pelvic girdle muscles, but also there were distal pareses. The proximal muscles were atrophic. No fasciculations, sensory or sphincteric symptoms were present. Cranial nerves were intact. Tendon reflexes were absent. Spinal column: flexion was impossible, extension limited. There was a fixed lumbar hyperlordosis with scoliosis.

Radiographs revealed no osseous pathology; there was narrowing of the intervertebral spaces at all levels, and Sshaped scoliosis. ECG showed atrial fibrillation. Echocardiography revealed no cardiomyopathy. Laboratory findings: CK levels in blood were slightly elevated (3 times normal value) and alphaglucosidase was normal in leucocytes. No other abnormalities. EMG did not show a clearly myopathic pattern. Some active denervation was seen in proximal muscles. There were normal motor and sensory conduction velocities.

Muscle biopsy findings (table 1): Light microscopy of an erector trunci muscle biopsy specimen revealed that nearly all fibres were replaced by connective and fatty tissue $(85 \%)$. The remaining fibres were extremely atrophied. There was no evidence of a primary neurogenic or myogenic cause.
There was a type II fibre predominance. Electron microscopy provided no additional information.

This patient showed a severe progressive and extensive illness, with a rigid spine as a symptom. The clinical picture is rather similar to that of the Emery Dreyfuss syndrome. The cardial rhythm disturbances also suggest this diagnosis.

\section{Discussion}

The rigid spine syndrome appears to be a distinct clinical entity characterised by limitation of flexion of the cervical and dorsolumbar spine, caused by a shortening or contracture of the spinal extensors, without severe pareses. It is a slowly progressive axial and proximal muscle disorder with joint contractures and scoliosis. The symptom of flexion limitation of cervical and dorsolumbar spine, however, are nonspecific. ${ }^{1920}$ In a literature survey (table 2) of the

Table 2 Literature survey of the rigid spine syndrome $e^{4-16}$

\begin{tabular}{|c|c|c|}
\hline $\begin{array}{l}\text { Number of cases } \\
\text { Mode of inheritance } \\
\text { Age of onset }\end{array}$ & $\begin{array}{l}23 ; 69,17 \delta \\
\text { all sporadic } \\
1-7 \text { year }\end{array}$ & \\
\hline Signs and symptoms & $\begin{array}{l}\text { - rigid spine } \\
\text { - flexion contractures } \\
\text { - scoliosis } \\
\text {-mild muscle weakness } \\
\text { - little subcutaneous fat } \\
\text { - walking problems }\end{array}$ & $\begin{array}{r}100 \% \\
92 \% \\
83 \% \\
61 \% \\
17 \% \\
57 \%\end{array}$ \\
\hline Course & $\begin{array}{l}\text { - mild progression } \\
\text { - no progression }\end{array}$ & $\begin{array}{l}70 \% \\
30 \%\end{array}$ \\
\hline Cardial pathology & $\begin{array}{l}\text { - cardiomyopathy } \\
\text {-other }\end{array}$ & $\begin{array}{r}9 \% \\
22 \%\end{array}$ \\
\hline CK & $\begin{array}{l}\text { - not/slightly elevated } \\
\text {-depressed }\end{array}$ & $\begin{array}{r}96 \% \\
4 \%\end{array}$ \\
\hline EMG & $\begin{array}{l}\text { - myopathic } \\
\text { - normal } \\
\text { - not examined }\end{array}$ & $\begin{array}{r}92 \% \\
4 \% \\
4 \%\end{array}$ \\
\hline Muscle biopsy & $\begin{array}{l}\text { - myopathic } \\
\text { - type I fibre predominance } \\
\text { - type II fibre predominance }\end{array}$ & $\begin{array}{r}100 \% \\
26 \% \\
13 \%\end{array}$ \\
\hline
\end{tabular}



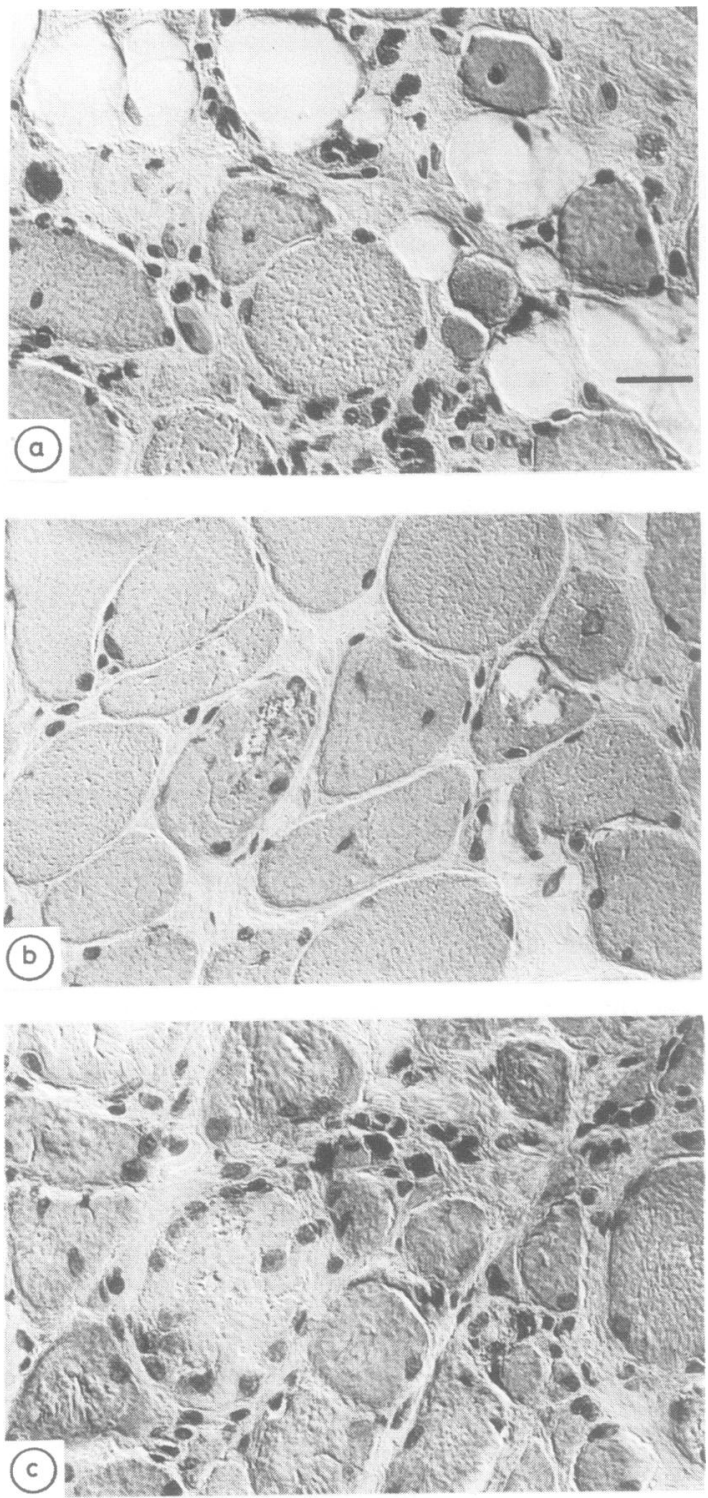

Fig 4 Endomysial connective tissue proliferation in psoas muscle $(A)$, intercostalis muscle $(B)$ and diaphragma muscle $(C)$. Note the presence of internal nuclei and rounded atrophic fibres $(A, B, C)$, fat cells $(A)$, vacuoles $(B)$, and $a$ pale large necrotic muscle fibre filled with some macrophages (C) (haematoxylin and eosin, bar $25 \mu \mathrm{m}$ ).

rigid spine syndrome we found 19 cases, five females and 14 males. So, genetically the rigid spine syndrome is not an X-linked disease as originally suggested. ${ }^{1112142122}$ The diagnosis is based on clinical symptoms and signs. A muscle biopsy is not patho- gnomonic. CK levels are not or only slightly elevated. EMG often shows a myopathic pattern.

For the differential diagnosis the most important feature is limitation of flexion of the cervical and dorsolumbar spine in the absence of severe weakness. Especially muscular dystrophy type Rotthauwe, ${ }^{21}$ type Emery-Dreyfuss, ${ }^{23}{ }^{24}$ type Thomas, ${ }^{25}$ and some congenital myopathies (minicore, fibre type disproportion, centronuclear, central core ${ }^{20}$ type Duchenne and type Becker ${ }^{26}$ spinal muscular atrophy, and congenital muscle dystrophy ${ }^{27}$ ) could give rise to confusion with the rigid spine syndrome in that they all cause early contractures and also a rigid spine, but also in progressive muscular dystrophy the rigid spine syndrome has been described. For the differential diagnosis of the rigid spine syndrome the following criteria seem to be important:

clinically: the distribution of muscular pathology. This is very restricted in the rigid spine syndrome. Furthermore, early (although not congenital) contractures and severe pareses do not occur in the rigid spine syndrome.

$E C G$ or echocardiography: in rigid spine syndrome cardiomyopathy is not a common feature.

genetically: in rigid spine syndrome sex-linkage is improbable.

time of onset: rigid spine syndrome has its onset in childhood.

In cases 1 and 2 the main features of the illness were limitation of flexion of the cervical and dorsolumbar spine. Already in the early onset flexion contractures of elbows and pelvic girdle were present. There were mild pareses of shoulder and pelvic girdle. The ECG showed no cardiomyopathy. CK levels were slightly elevated. EMG of the erector trunci showed a myopathic pattern. Radiographs revealed no osseous pathology. There was no X-linkage. The fatal, relatively rather rapid course of case 1 must be considered as secondary to the dystrophic illness of the axial musculature, diaphragm and intercostal muscles with progressive respiratory insufficiency. These two cases and also 19 cases in the literature most probably could be classified as rigid spine syndrome. However, two of these 19 cases showed a cardiomyopathy and possibly should not be so classified. ${ }^{913}$ In many other myopathic diseases and in cases 3 and 4 there was also flexion limitation and rigid spine. In case 3 congenital hypotonia and contractures were diagnostically more important and in case 4 severe progressive muscle weakness in addition to contractures were the main problem.

In the literature there has been discussion of possible X-linked inheritance. As female cases are described, there seems to be no X-linkage. There is no therapy. Immunosuppressive therapy and anabole steroids have not been successful. The aetiology is still 
unknown. Twice, in our cases 1 and 2 , the biopsy of the paraspinal muscles resembled "inclusion body myositis".

It may be better to consider the rigid spine syndrome (Dubowitz $\left.{ }^{1-4}\right)$. Only when a rigid spine is the most important feature is it justified to speak of a rigid spine syndrome as described by Dubowitz. However, the rigid spine syndrome perhaps also is not a single well defined disease entity, as is emphasised in a recent report. ${ }^{16}$

We thank Prof Dr SLH Notermans for electroneurophysiological studies, Prof Dr HOM Thijssen for radiological investigations, Prof Dr HAD Walder for performing the muscle biopsies, Prof $\mathrm{Dr}$ AM Stadhouders for electron microscopic studies and $\mathrm{Dr}$ KJB Lamers for biochemical studies.

\section{References}

${ }^{1}$ Dubowitz V. Pseudo-muscular dystrophy. In: Research in Muscular Dystrophy. Proceedings of the Third Symposium. Research Committee of the Muscular Dystrophy Group of Great Britain. London: Pitman Medical, 1965:57-73.

${ }^{2}$ Dubowitz V. Some unusual neuromuscular disorders. In: Walton JN, Canal N, Scarlato G, eds. Muscle Diseases. Proceedings of an International Congress. Milan, 1969. Amsterdam: Excerpta Medica, 1970:233-8.

${ }^{3}$ Dubowitz V. Recent advances in neuromuscular disorders. Rheumatol Phys Med 1971;11:126-30.

${ }^{4}$ Dubowitz V, Brooke MH. Rigid spine syndrome. Muscle biopsy. A modern approach. In: Major Problems in Neurology Vol 2 London, WB Saunders Co, 1973:368-71.

${ }^{5}$ Goebel HH, Lenard HG, Görke W, Kunze K. Fibre type disproportion in the rigid spine syndrome. Neuropädiatrie 1977;8:467-77.

${ }^{6}$ Seay AR, Ziter FA, Petajan JH. Rigid spine syndrome. A type I fiber myopathy. Arch Neurol 1977;34:119-22.

${ }^{7}$ Goto I, Nagasaka S, Nagara H, Kuroiwa Y. Rigid spine syndrome. J Neurol Neurosurg Psychiatry 1979;42: 276-9.

${ }^{8}$ Goto I, Muraoka S, Fujii N, Ohta M, Kuroiwa Y. Rigid spine syndrome: clinical and histological problems. J Neurol 1981;226:143-8.

${ }^{9}$ Colver AF, Steer CR, Godman MJ, Uttley WS. Rigid spine syndrome and fatal cardiomyopathy. Arch Dis Child 1981;56:148-51.

${ }^{10}$ Mussini J-M, Mathé J-F, Prost A, Gray F, Labat J-J, Fève J-R. Le syndrome de la colonne raide. Un cas féminin. Rev Neurol (Paris) 1982;138:25-37.

${ }^{11}$ Vogel P, Goebel HH, Seitz D. Rigid spine syndrome in a girl. J Neurol 1982;228:259-65.

${ }^{12}$ Dubowitz V. Muscle disorders in childhood. London, WB Saunders, 1978:239-43.
${ }^{13}$ Théry CL, Krivosic I, Dewailly PH, Pirot J, Lablauche JM, Jaillard J. Cardiomyopathy congestive associée à un syndrome de la colonne raide. "Rigid spine syndrome". Arch Mal Coeur 1981;8:985-91.

${ }^{14}$ Loesner J, Oertel G, Ziegan J. Rigid spine-syndrome. Seltene Kombination mit einer neuromuskulären Affektion. Beitr Orthop Traumatol 1981;28:429-33.

${ }^{15}$ Mussini JM, Gray F, Hauw JJ, Piette AM, Prost A. Rigid spine syndrome. Histological examination of male and female cases. Acta Neuropathol (Berl) 1981;Suppl VII:331-3.

${ }^{16}$ Poewe W, Willeit H, Sluga E, Mayr U. The rigid spine syndrome: a myopathy of uncertain nosological position. J Neurol Neurosurg Psychiatry 1985;48:887-93.

${ }^{17}$ Sulaiman A, Swick HM, Kinder DS. Congenital fibre type disproportion with unusual clinico-pathologic manifestations. J Neurol Neurosurg Psychiatry 1983;46: 175-82.

${ }^{18}$ Carpenter S, Karpati G, Eisen A. A morphologic study of muscle in polymyositis. Clues to pathogenesis in different types. In: Walton SN, Bradley WA, eds. Recent Advances in Myology. Proceedings Third International Congress in muscle diseases. Amsterdam: Excerpta Medica, 1975:377-9.

${ }^{19}$ Antonescu D, Filipescu G, Roventa N, et al. Rigid spine syndrome: considerations with reference to 2 cases. In: Pecina M, ed. Scoliosis and Kyphosis. Abstracts of the 1st European Congress on Scoliosis and Kyphosis (October 5-9, 1983, Dubrovnik). Zagreb, Yugoslavia: Sveucilisna Naklada Liber, 1983:147.

${ }^{20}$ Granata E, Merlini L, Saivini R. The rigid spine in several types of myopathy. In: Pecina M, ed. Scoliosis and Kyphosis. Abstracts of the 1st European Congress on Scoliosis and Kyphosis (October 5-9, 1983, Dubrovnik). Zagreb, Yugoslavia: Sveucilisna Naklada Liber, 1983:159.

${ }^{21}$ Rotthauwe HW, Mortier W, Beyer H. Neuer Typ einer recessiv X-chromosomal vererbten Muskeldystrophie, Scapulo-humero-distale Muskeldystrophie mit frühzeitigen Kontrakturen und Herzrhythmusstörungen. Humangenetik 1972;16:181-200.

${ }^{22}$ Echenne B, Astruc J, Brunel D. Congenital muscular dystrophy and rigid spine syndrome. Neuropediatrics 1983;14:97-101.

${ }^{23}$ Emery AEH, Dreifuss FE. Unusual type of benign Xlinked muscular dystrophy. J Neurol Neurosurg Psychiatry 1966;29:338-42.

${ }^{24}$ Wadia RS, Wadgaonkar SU, Amin RB, Sardesai HV. An unusual family of benign " $\mathrm{X}$ " linked muscular dystrophy with cardiac involvement. $J$ Med Genet 1976;13:352-6.

${ }^{25}$ Thomas PK, Calne DB, Elliott CF. X-linked scapuloperoneal syndrome. J Neurol Neurosurg Psychiatry 1972;35:208-15.

${ }^{26}$ Becker PE, Kiener F. Eine neue X-chromosomale Muskeldystrophie. Archiv Psychiatr Z Neurol 1955;193: 427-48.

${ }^{27}$ Vassella F, Mumenthaler M, Rossi E, Moser H, Wiesmann U. Die kongenitale Muskeldystrophie. Dtsch Z Nervenheilk 1967;190:349-74. 